\title{
Pornografi Ditinjau dari \\ Hukum Positif dan Hukum Pidana Islam
}

\author{
Siti Risdatul Ummah \\ VIN Sunan Ampel Surabay | risdawae@gmail.com
}

\begin{abstract}
At the present time the development of social media so rapidly, which of course affect the pattern of community life. But this development is often misused, one of which is cyberpor. This paper aims to describe and analyze pornography in the perspective of Indonesian Penal Code and Islamic Criminal Law. At the end of the paper it is concluded that, first, pronography in Indonesian criminal law is defined as drawings, sketches, illustrations, photographs, writings, sounds, sounds, moving pictures, animations, cartoons, conversations, gestures, or other forms of communication through various forms of communication media and/or public performances, containing obscenity or sexual exploitation in violation of moral norms in society. The regulation is contained in the Criminal Code (Article 282), in Act Number 44 of 2008 on Pornography, and in Law Number 11 Year 2008 on Information and Electronic Transactions. Secondly, that pornography in Islamic Law includes adultery that is not punished (hadd), but still makes the perpetrators sinful. The sanction for the perpetrators of pornography is $t a^{\prime} z i r$, which the determination of sanctions is the right of the state leader in accordance with the level of crime committed.
\end{abstract}

\begin{abstract}
Abstrak: Pada masa sekarang perkembangan media social begitu pesatnya, yang tentunya mempengaruhi pola hidup masyarakat. Namun perkembangan ini sering disalah gunakan, salah satunya adalah cyberpor. Tulisan ini ingin mengkaji dan menganalisis pornografi dalam prespektif Hukum Pidana Indonesia dan Hukum Pidana Islam. Di akhir tulisan disimpulkan bahwa, pertama, pronografi dalam hokum pidana Indonesia didefinisikan sebagai gambar, sketsa, ilustrasi, foto, tulisan, suara, bunyi, gambar bergerak, animasi, kartun, percakapan, gerak tubuh, atau bentuk pesan lainnya melalui berbagai bentuk media komunikasi dan/atau pertunjukan di muka umum, yang memuat kecabulan atau eksploitasi seksual yang melanggar norma kesusilaan dalam masyarakat. Pengaturannya
\end{abstract}


terdapat dalam KUHP (Pasal 282), dalam Undang-undang Nomor 44 Tahun 2008 tentang Pornografi, dan dalam Undang-undang Nomor 11 Tahun 2008 Tentang Informasi dan Transaksi Elektronik. Kedua, bahwa pornografi dalam Hukum Islam termasuk zina yang tidak sampai terkena hukuman (hadd), namun tetap membuat pelakunya berdosa. Sanksi bagi pelaku pornografi adalah ta'zír, yang penetapan kadar sanksi merupakan hak bagi pemimpin negara sesuai dengan tingkat kejahatan yang dilakukan.

Kata kunci: pornografi, hokum pidana Indonesia, hokum pidana Islam

\section{A. Pendahuluan}

Media sosial mampu memberikan kemudahan bagi para pengguna untuk berkomunikasi dan bersosialisasi. ${ }^{1}$ Dengan kemudahan-kemudahan yang disediakan, tentu saja media sosial lebih diminati oleh masyarakat dibanding dengan media tradisional. Kemudahan-kemudahan yang dimaksud yaitu media sosial tidak dibatasi oleh tempat dan waktu, yang artinya siapapun dapat menggunakan media sosial di mana saja dan kapan saja, asalkan memiliki akses internet. $^{2}$ Dari sinilah, media sosial semakin berkembang dan semakin diminati oleh masyarakat. ${ }^{3}$

Dengan semakin tingginya minat masyarakat terhadap media sosial, maka masyarakat akan semakin tergantung dengan media sosial, dan hal ini akan mempengaruhi kehidupan mereka sehari-hari. ${ }^{4}$ Anggapan yang mengatakan bahwa internet identik dengan pornografi, memang tidak salah. Dengan kemampuan penyampaian informasi yang dimiliki internet, pornografi pun merajalela. Di internet terdapat gambar-gambar pornografi yang bisa

${ }^{1}$ Eni Maryani, Media dan Perubahan Sosial, (Jakarta: Rosda. 2011), h. 17.

2 Ibid., h. 21

${ }^{3}$ Ibid., h. 23

${ }^{4}$ Soetandyo Wignjosoebroto, Pergeseran dalam Kajian-kajian Sosial dan Hukum, (Bandung: Setara Press, 2013), h. 45. 
mengakibatkan dorongan kepada seseorang untuk bertindak kriminal. 5

Salah satu media pornografi yang sekarang lagi marak adalah internet, yang biasa disebut dengan cyberporn. Salah satu yang paling banyak digunakan adalah aplikasi media sosial Bigo Live, yang merupakan aplikasi berbasis Android dengan menggunakan IOS. Dari deskripsinya, Bigo Live digunakan untuk menyiarkan aktivitas sehari-hari broadcaster (penyiar) ke member Bigo Live lainnya. Pada halaman muka, akan disuguhkan dengan beragam pilihan broadcaster Bigo Live yang dapat ditonton siarannya. ${ }^{6}$ Ketika masuk, akan dapat melihat broadcaster beraksi dan berinteraksi dengan pengunjung, dan dapat mengirim pesan atau mengirim hadiah ke broadcaster favorit. Dari berbagai banyak pilihan broadcaster, sebagian besar dari mereka didominasi perempuan. Namun sayangnya, para broadcaster ini tampil berpakaian seksi dan terlihat menunjukkan bagian vital mereka ke publik. ${ }^{7}$

Yang membuat aplikasi ini digemari oleh para pengguna adalah karena aplikasi ini mempunya beberapa keistimewaan. Salah satu keistimewaannya bahwa broadcaster dapat menghasilkan uang cash dari hasil Broadcasting secara live. Semakin banyak orang yang memberikan Gift kepada broadcaster maka akan semakin banyak Diamond terkumpul, yang pada akhirnya nanti Diamond tersebut bisa ditukarkan menjadi uang cash, minimal penarikan adalah 6700 diamond atau setara dengan

5 Muhammad Ihrom, "Pornografi di Internet", dalam https://muhammad26ihrom.wordpress.com/cyber- crime-dan-cyberlaw/pornografi-di-internet, diakses 09/03/2017.

6 David Le, " All About Bigo Live", dalam http://www.Bigo.Sg/About.Html, diakses 17/01/2017.

7 Nana Mandani, "Mengapa Wanita Rela Umbar Aurat di Bigo Live?Ternyata ini Imbalannya", dalam Tribun News, (27 Agustus 2016), h. 1 . 
Rp. 2.000.000. Dengan sebab inilah broadcaster rela berbuat tindakan asusila ${ }^{8}$

Saat ini masalah cyberporn semakin memprihatinkan dan dampak negatifnya semakin nyata. Pemerintah secara tegas telah mengambil langkah nyata membendung arus cyberporn serta cybercrime lainnya, dengan membentuk undang-undang RI Nomor 11 Tahun 2008 Tentang Informasi dan Transaksi Elektronik dan telah disahkan pada tanggal 21 April 2008. ${ }^{9}$ Didalam undang-undang tersebut, yaitu cyberporn telah diatur dalam pasal 27 ayat (1) Tentang perbuatan yang dilarang, yang berbunyi : ${ }^{10}$

"Setiap orang dengan sengaja dan tanpa hak mendistribusikan dan/atau mentransmisikan dan/atau membuat dapat diaksesnya informasi elektronik dan/atau dokumen elektronik yang memiliki muatan melanggar kesusilaan".

Penerapan ketentuan pasal kesusilaan ini jelas akan merujuk pada ketentuan peraturan perundang-undangan lainnya yang secara khusus mengatur pornografi yakni UU No 44 Tahun 2008 Tentang Pornografi dan pasal 282 KUHP Tentang Pornografi. 11

Sedangkan dalam dalam agama Islam, larangan untuk melihat atau memperlihatkan aurat, mendekati perbuatan zina, serta perintah untuk menjaga kehormatan, tertuang jelas dalam Al-Qur'An, Hadis, serta dalam kaidah-kaidah Fiqh dan Ushul Fiqh. Sebab agama Islam sangat peduli dalam mengatur tentang adab kesusilaan dan menjaga kehormatan.

8 Dimas Maulana, "Bigo live, Kenapa Bisa Tenar?", dalam https://www.kaskus.co.id/thread/578f74fb 507410f0718b456a/aplikasibigo-live-kenapa-bisa-tenar/, diakses 20/01/2017.

9 Budi Suhariyanto, Tindak Pidana Teknologi Informasi (Cyber Crime), (Jakarta: Rajagrafino Persada, 2013), h. 104.

10 Undang-undang Nomor 11 Tahun 2008 tentang Informasi dan Transaksi Elektronik

${ }^{11}$ Hidayat Lubis, Tinjauan Hukum Pidana Islam Terhadap Cyberporn Pada UU RI Nomor 11 Tahun 2008 Tentang Informasi Dan Transaksi Elektronik, (skripsi--UIN Sunan Kalijaga, 2009). 
Islam mewajibkan menutup aurat dan haram hukumnya untuk melihat ataupunmemperlihatkannya. ${ }^{12}$

Dalam pandangan hukum Islam, adalah perbuatan yang dilarang (haram). pengharaman pornografi terkait erat dengan pengaturan menutup aurat dengan pemahaman tentang perzinaan. Dengan demikian, kriteria porno dalam kamus Islam adalah semua produk (gambar, tulisan, suara $\mathrm{dsb}$ yang mempertontonkan, mendeskripsikan, menguraikan segala hal tentang aurat pria dan wanita tanpa tujuan yang dibenarkan syar'i seperti untuk pendidikan, medis, hukum atau penelitian. ${ }^{13}$ Segala perbuatan-perbuatan yang melanggar kesusilaan dan melecehkan kehormatan, serta segala hal yang dapat mengarahkan pada perzinaan adalah hal yang diharamkan dalam Islam.

Lebih konkritnya adalah larangan Allah SWT. Dalam QS. Al-Isrā' (17): 32 yang berbunyi:

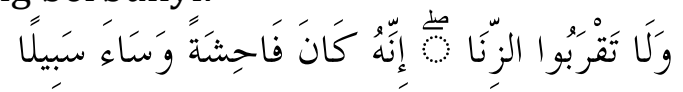

Artinya: "Dan janganlah kamu mendekati zina; Sesungguhnya zina itu adalah suatu perbuatan yang keji. dan suatu jalan yang buruk."

Dan juga dalam QS. Al-Aḥzāb (33): 59 disebutkan:

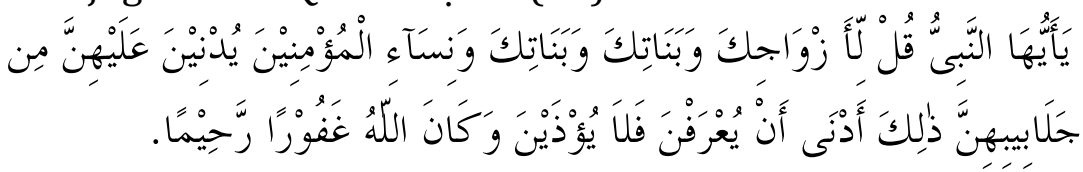

Artinya: "Hai Nabi! Katakanlah kepada istri-istrimu, anakanak perempuanmu dan isteri-isteri orang mukmin, 'hendaklah mereka mengulurkan jilbabnya ke seluruh tubuh mereka'. Yang demikian itu supaya mereka lebih mudah untuk dikenal, karena itu mereka tidak diganggu. Dan Allah adalah Maha Pengampun lagi Maha Penyayang."

Sedangkan dalam kaidah fiqh disebutkan:

12 Neng Djubaedah, Pornografi dan Pornoaksi Ditinjau dari Hukum Islam, (Jakarta: Kencana, 2003), h. 36 .

13Ibid., h. 40. 


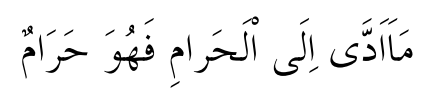

(apa saja yang mendorong pada perbuatan haram maka itu adalah haram). Dengan demikian, maka perlu melakukan antisipasi kepada hal-hal yang bisa mengarah pada menyebabkan terjadinya hal yang dilarang, yang dalam hal ini adalah pronografi.

Dengan memperhatikan fenomena cyberporn yang begitu marak tersebut, yang menimbulkan dampak kerusakan moral yang meresahkan masyarakat, maka menjadi perlu melakukan kajian mendasar tentang cyber porn. Tentunya kajian tersebut itu dari aspek batasan, prespektif hukum positif dan prespektif hukum Islam, dan inilah yang menjadi tujuan dari penulisan ini.

\section{B. Pornografi dan Cyberporn. \\ 1. Pornografi}

Pornografi merupakan Istilah yang berasal dari bahasa Yunani, pornographia. Istilah ini bermakna tulisan atau gambaran tentang pelacur. ${ }^{14}$ Pornografi merupakan penggambaran tubuh manusia atau perilaku seksualitas manusia secara terbuka (eksplisit) dengan tujuan membangkitkan birahi (gairah seksual). Pornografi berbeda dari erotika. Dapat dikatakan, pornografi adalah bentuk ekstrem/vulgar dari erotika. Erotika sendiri adalah penjabaran fisik dari konsep-konsep erotisme. Kalangan industri pornografi kerap kali menggunakan istilah erotika dengan motif eufemisme namun mengakibatkan kekacauan pemahaman di kalangan masyarakat umum. ${ }^{15}$ Dalam Kamus Besar Bahasa Indonesia dikatakan bawah pornografi bermakna dua, pertama adalah merupakan penggambaran tingkah laku secara erotis dengan lukisan atau tulisan untuk

${ }^{14}$ Azimah Soebagijo, Pornografi Dilarang Tapi Dicari, (Jakarta: Gema Insani, 2008), h. 17.

15 Admin, "Pornografi", dalam https://id.wikipedia.org/wiki/Pornografi, diakses 20/01/2017. 
membangkitkan nafsu berahi; dan kedua adalah bahan bacaan yang dengan sengaja dan semata-mata dirancang untuk membangkitkan nafsu berahi dalam seks. ${ }^{16}$

Kata ini pertama kali muncul di Inggris pada masa Ratu Victoria (1837-1901). Ketika itu arkeolog baru saja menemukan peninggalan benda-benda bersejarah (artefak) dari penggalian bekas kota Pompei dan Herculanum dekat Napoli di Italia Selatan. ${ }^{17}$ Karena hal itulah masyarakat Eropa ketika itu menyimpulkan bahwa benda peninggalan seperti itu berhubungan dengan tempat pelacuran sehingga kemudian lahirlah istilah pornografi (tulisan/gambar tentang pelacur).

Sejarah kemunculan pornografi adalah pada masa paleolitikum telah ada manusia telanjang dan aktvitasaktivitas seksual, seperti patung venus. Pada reruntuhan bangunan Romawi di Pompei, ditemukan lukisan-lukisan porno. Selain itu disisi-sisi jalan di Pompei juga dapat dijumpai gambar-gambar alat kelamin pria yang dahulunya digunakan sebagai petunjuk jalan menuju ke tempat pelacuran dan hiburan. Seiring dengan revolusi industri yang menghasilkan banyak penemuan-penemuan, seperti mesin cetak dan fotografi, media pornografi pun mulai beralih. Pada awalnya pornografi hanya ditulis, diukir dan di lukis di daun-daun, kulit-kulit pohon, batu-batu dan temboktembok, tetapi dengan penemuan tersebut pornografi dapat dicetak dalam jumah yang banyak, seperti dalam bentuk majalah, koran dan komik. ${ }^{18}$

Ragam pornografi dibagi menjadi dua yaitu ragam pornografi berdasarkan muatannya dan ragam pornografi berdasarkan mediumnya. ${ }^{19}$ Ragam pornografi berdasarkan

16 Admin, "Pornografi", dalam https://kbbi.web.id/pornografi, diakses 20/01/2017.

${ }^{17}$ Azimah Soebagijo, Pornografi Dilarang Tapi Dicari, h. 26.

18Indra Perwira, "Sejarah Pornografi", dalam Bima Sakti, 03, (15 Mei 2015), h. 3.

${ }^{19}$ Azimah Soebagiy, Pornografi Dilarang Tapi Dicari, h. 34. 
mediumnya adalah sexually violent material (materi pornografi dengan menyertakan kekerasan), nonvioent material depicting degradation, domination, subordinatio, or humiliation (Jenis ini tidak menggunakan kekerasan dalam materi seks yang disajikannya), nonviolent and nondegrading materials (prodak media yang membuat adegan hubungan seksual tanpa unsur kekerasan atau pelecehan terhadap perempuan), nudity (materi seksual yang menampilkan model telanjang), child pornography adalah produk media yang menampilkan anak atau remaja sebagai modelnya. ${ }^{20}$ Sedangkan Ragam pornografi berdasarkan mediumnya adalah media elektronik, media cetak dan media luar ruang. ${ }^{21}$

\section{Dampak Pornografi}

Dampak dari pornografi sangat berbahaya, karena mengkonsumsi pornografi dapat menimbulkan efek negatif bagi perkembangan psikologis dan biologis. Catherine Mackinnon menyatakan bahwa "pornografi didunia maya adalah pornografi dalam lingkup lebih luas, lebih dalam, lebih buruk, dan lebih banyak ("pornography in cyberspace is pornography in society-just broader, deeper, worse and more of $\left.i t^{\prime \prime}\right) .22$ Sejalan dengan perkembangan teknologi informasi dan komunikasi saat ini terjadi peningkatan pornografi dan pornoaksi dalam berbagai bentuknya. Kecenderungan ini telah menimbulkan keresahan dan kekuatiran masyarakan beragama akan hancurnya sendisendi moral dan etika. ${ }^{23}$

Pornografi merupakan akar permasalahan yang akan menimbulkan berbagai permasalahan sosial, seperti penyimpangan perilaku, pelacuran, seks bebas, penyakit

${ }^{20}$ Ibid., h. 36.

21 Ibid., h. 40.

22 Ibid., h. 51.

23 Adi Maulana, Blokir Pornografi, (Bandung: Nuansa Cendikia, 2012), h. 35.

Al-Qānūn, Vol. 20, No. 2, Desember 2017 
mematikan dan merosotnya moral generasi penerus bangsa. ${ }^{24}$

Kecanduan pornografi di internet dapat menimbulkan beberapa dampak negatif, yaitu:

a. Dari segi finansial, pelaku akan menghabiskan banyak waktu untuk mengakses materi-materi tersebut yang otomatis meningkatkan biaya akses internet. Bahkan, uang mereka bisa dihabiskan untuk berlangganan pornografi komersial.

b. Bagi perkembangan pribadi, pornografi bisa menyebabkan seseorang menjadi budak nafsu,turunnya konsentrasi, malas kerja keras, suka berbohong, suka berkhayal, sampai kehilangan orientasi masa depan. ${ }^{25}$

\section{Cyberporn}

Cyberporn adalah "materi pornografi yang tersedia online" ("pornographic material available online"). ${ }^{26}$ Sementara dalam encyclopedia.thefreedictionary.com, definisi internet pornography adalah " pornography that is distributed via the internet, primarily via websites, peer to peer file sharing, or usenet news groups".

Definisi tersebut menunjukan bahwa cyberporn merupakan penyebaran bahan-bahan atau materi-materi pornografi melalui internet, baik itu tulisan, gambar, foto, suara maupun film/video. Materi-materi pornografi di internet dapat dijumpai pada situs-situs porno, situs-situs media informasi seperti situs majalah dan koran. Misalnya situs playboy.com atau situs-situs hiburan dan lainya. Di dunia maya tersedia ratusan bahkan ribuan situs porno yang dapat dijumpai dan dibuka setiap saat. ${ }^{27}$

24 Ibid., h. 38.

25 Ibid., h. 40.

26 Rahma Maula, "Devinisi Cyberporn", dalam http://www.computeruser.com/resaurces/dictionary/searcher.html?q=1\& $o b j=C$, diakses 05/04/2017.

27 Adi Basuki, "Definisi Internet Pornography", dalam http://encyclopedia.thefreedictionary.com, diakses 05/04/2017. 
Cyberporn merupakan bentuk media pornografi yang strategis bagi industri pornografi. Penyebaran pornografi melalui internet akan lebih mudah, lebih murah, sangat cepat dan yang paling penting adalah aman dari razia aparat. Pada proses distribusi pengelola situs porno cukup dengan memasukkan materi pornografi ke dalam situs yang dimilikinya. Jadi tidak perlu biaya dan waktu yang lama untuk mendistribusikannya ke agen-agen secara sembunyisembunyi. Keuntungan lainnya adalah cyberporn tidak perlu mencari-cari konsumen, tetapi konsumenlah yang dengan sendirinya akan mencari dan membuka situs-situs porno untuk sekedar melihat, mendownload atau sampai dengan membeli dan memesan produk pornografi yang ditawarkan. ${ }^{28}$

Cyberporn memiliki cakupan yang luas, dalam arti hampir semua bentuk pornografi ada didalamnya. Mulai dari tulisan sampai dengan komunikasi interaktif. Dalam sebuah situs porno terdapat berbagai pilihan fitur atau layanan, mulai dari cerita-cerita porno, video porno, tips-tips porno, foto-foto porno, suara atau audio porno, komunikasi interaktif baik audio maupun audio visual, bahkan ada juga pelacuran on-line. ${ }^{29}$

\section{Pornografi Ditinjau Dari Hukum Positif \\ 1. Pengaturan Pornografi dalam KUHP}

Dalam KUHP, pornografi merupakan kejahatan yang termasuk golongan tindak pidana melanggar kesusilaan yang termuat dalam Pasal 282, yaitu:

a. Barang siapa menyiarkan, mempertunjukkan atau menempelkan dimuka umum tulisan, gambaran atau benda yang telah diketahui isinya melanggar kesusilaan, atau barang siapa dengan maksud untuk disiarkan, dipertunjukkan atau ditempelkan dimuka umum,

${ }^{28}$ Adi Maulana, Blokir Pornografi, h. 48.

29 Arief, Pornografi Pornoaksi dan Cybersex Cyberporn, (Semarang: Pustaka Magister, 2011), h. 48. 
membuat tulisan, gambaran atau benda tersebut, memasukkannya ke dalam negeri, meneruskannya, mengeluarkannya dari negeri, atau memiliki persediaan, ataupun barang siapa secara terang-terangan atau dengan mengedarkan surat tanpa diminta, menawarkannya atau menunjukkannya sebagai bisa diperoleh, diancam dengan pidana penjara paling lama satu tahun enam bulan atau pidana denda paling tinggi empat ribu lima ratus rupiah.

b. Barang siapa menyiarkan, mempertunjukkan atau menempelkan di muka umum tulisan, gambaran atau benda yang melanggar kesusilaan, ataupun barang siapa dengan maksud untuk disiarkan, dipertunjukkan atau ditempelkan di muka umum, membikin, memasukkan ke dalam negeri, meneruskan mengeluarkannya dari negeri, atau memiliki persediaan, ataupun barang siapa secara terang-terangan atau dengan mengedarkan surat tanpa diminta, menawarkan, atau menunjuk sebagai bisa diperoleh, diancam, jika ada alasan kuat baginya untuk menduga bahwa tulisan, gambaran atau benda itu melanggar kesusilaan, dengan pidana paling lama sembilan bulan atau pidana denda paling banyak empat ribu lima ratus rupiah.

c. Kalau yang bersalah melakukan kejahatan tersebut dalam ayat pertama sebagai pencarian atau kebiasaan, dapat dijatuhkan pidana penjara paling lama dua tahun delapan bulan atau pidana denda paling banyak tujuh puluh lima ribu rupiah.

Perbuatan-perbuatan yang tercantum dalam Pasal 282 KUHP baik yang terdapat dalam ayat (1), (2) maupun (3) dapat digolongkan menjadi tiga macam, ${ }^{30}$ yaitu:

a. Menyiarkan, mempertontonkan atau menempelkan dengan terang-terangan tulisan dan sebagainya.

${ }^{30}$ Andi Hamzah, DelikdDelik Tertentu di dalam KUHP, (Jakarta: Sinar Grafika, 2014), h. 154. 
b. Membuat, membawa masuk, mengirimkan langsung, membawa keluar ataumenyediakan tulisan dan sebagainya untuk disiarkan, dipertontonkan atau ditempelkan dengan terang-terangan.

c. Dengan terang-terangan atau dengan menyiarkan suatu tulisan menawarkan dengan tidak diminta atau menunjukkan, bahwa tulisan dan sebagainya itu boleh di dapat.

\section{Undang-undang Nomor 44 Tahun 2008 tentang Pornografi}

Sejak tahun 2006 telah bergulir pembahasan Rancangan Undang-Undang Anti Pornografi dan Pornoaksi (RUU APP) di Dewan Perwakilan Rakyat Republik Indonesia. Dalam perjalanannya, RUU APP berganti menjadi RUU Pornografi dan pada tanggal 30 Oktober 2008, DPR RI mengesahkan UU Pornografi melalui Sidang Paripurna dengan nama Undang-Undang Nomor 44 Tahun 2008 tentang pornografi. ${ }^{31}$

Pasal 1 angka 1 UU Pornografi menegaskan bahwa "Pornografi adalah gambar, sketsa, ilustrasi, foto, tulisan, suara, bunyi, gambar bergerak, animasi, kartun, percakapan, gerak tubuh, atau bentuk pesan lainnya melalui berbagai bentuk media komunikasi dan/atau pertunjukan di muka umum, yang memuat kecabulan atau eksploitasi seksual yang melanggar norma kesusilaan dalam masyarakat". ${ }^{32}$

Sedangkan pada Pasal 44 UU Pornografi menegaskan bahwa bagi orang yang memiliki website yang menyajikan cerita porno, foto bugil, film porno, dan berbagai informasi bermuatan pornografi akan dijerat dengan pasal 4 ayat (1) UU No. 44 Tahun 2008 tentang Pornografi dengan pidana penjara paling singkat 6 (enam) bulan dan paling lama 12

31 Adi Budiman, "Pornografi dan Hukum yang Mengaturnya", dalam http://www.pornografi-dan-hukum-mengaturnya-0=67, diakses 23/04/2017.

32 Undang-undang Nomor 44 Tahun 2008 tentang Pornografi. 
(duabelas) tahun dan/atau pidana denda paling sedikit Rp.250.000.000,00 (dua ratus lima puluh juta rupiah) dan paling banyak Rp.6.000.000.000,00 (enam miliar rupiah). ${ }^{33}$

Di dalam UU Pornografi terdapat 10 pasal yang merupakan pemidanaan bagi para pelaku tindak pidana pornografi. Dimana masing-masing pasal memuat ketentuan pidana penjara dan pidana denda, adapun ketentuan pidana tersebut dapat berupa pidana tunggal atau pidana kumulatif, artinya Hakim dapat saja menjatuhkan pidana penjara atau pidana denda ataupun pidana penjara dan pidana denda karena menggunakan frase "dan/atau". ${ }^{34}$

\section{Undang-undang Nomor 11 Tahun 2008 Tentang Informasi dan Transaksi Elektronik}

Indonesia telah memiliki peraturan perundangundangan yang memuat larangan penyebaran pornografi dalam bentuk informasi elektronik yakni UU No. 11 Tahun 2008 tentang Informasi dan Transaksi Elektronik (UU ITE). UU ITE mulai dirancang pada bulan maret 2003 oleh kementerian Negara komunikasi dan informasi (kominfo), pada mulanya RUU ITE diberi nama undang-undang informasi komunikasi dan transaksi elektronik oleh Departemen Perhubungan, Departemen Perindustrian, Departemen Perdagangan, serta bekerja sama dengan Tim dari universitas yang ada di Indonesia yaitu Universitas Padjajaran (Unpad), Institut Teknologi Bandung (ITB) dan Universitas Indonesia (UI).

Setelah perjalanan panjang selama lima tahun hingga pada tanggal 18 Maret 2008 merupakan naskah akhir UU ITE dibawa ke tingkat II sebagai pengambilan keputusan. 25 Maret 2008, 10 Fraksi menyetujui RUU ITE ditetapkan menjadi Undang-Undang. Selanjutnya Presiden Susilo Bambang Yudhoyono menandatangani naskah UU ITE menjadi Undang-Undang Republik Indonesia Nomor 11

33 Undang-undang Nomor 44 Tahun 2008 tentang Pornografi.

${ }^{34}$ Azimah Soebagijo, Pornografi Dilarang Tapi Dicari, h. 30. 
Tahun 2008 tentang Informasi dan Transaksi Elektronik, kemudian dimuat dalam Lembaran Negara Nomor 58 Tahun 2008.

Sedangkan pasal yang mengatur tentang larangan penyebaran pornografi di internet adalah pasal 27 ayat (1)UU No. 11 Tahun 2008 tentang Informasi dan Transaksi Elektronik (UU ITE) 35 dinyatakan bahwa :

"Setiap Orang dengan sengaja dan tanpa hak mendistribusikan dan/atau mentransmisikan dan/atau membuat dapat diaksesnya Informasi Elektronik dan/atau Dokumen Elektronik yang memiliki muatan yang melanggar kesusilaan."

Teks pasal 27 ayat (1) tersebut memiliki tiga unsur, diantaranya :

a. Unsur subjektif pada pelaku, yaitu unsur kesalahan.

Dengan tercantumnya "dengan sengaja", maka perlu dibuktikan menganai kesengajaan dari pelaku dalam hal melaksanakan delik yang diancamkan. Karena para pelaku cybercrime terkadang adalah hanya sekedar iseng atau bermain-main saja, tanpa ada niat dan motif yang sungguh-sungguh untuk kebutuhan ekonomi dirinya misalnya. ${ }^{36}$

b. Unsur melawan hukum

Dalam pasal ini tidak dijelaskan secara eksplisit bahwa yang dimaksud dengan "tanpa hak" adalah arti atau makna dari "melawan hukum". Sebagaimana jika diterjemahkan dalam bahasa Inggris, kata tersebut dapat diterjemahkan dengan "without right" yang digunakan dalam cyberlaw diberbagai negara yang berbahasa Inggris. Maka "tanpa hak" dapat diartikan sebagai "melawan hukum", hal ini didasarkan pada pengertian dasar dari elemen melawan hukum yang notabennya mempunyai istilah asing "onrechtmatigheid"

35 Undang-undang Informasi dan Transaksi Elektronik

36 Budi Suharianto, Tindak Pidana Teknologi Informasi, (Jakarta: Raja Grafindo Persada, 2013), h. 108. 
dalam kepustakaan mempunyai beberapa makna antara lain, yaitu melawan hukum (tagen het recht), tanpa hak sendiri (zonder eigen recht), bertentagan dengan hukum pada umumnya (in strijd met het recht in het algemeen), bertentangan dengan hak pribadi seseorang (in strijd met een anders subjectieve recht), bertentangan dengan hukum objektif (tegen het objectieve recht). ${ }^{37}$

c. Unsur kelakuan

Dalam pasal inidijelaskan terapat tiga perbuatan yang dilarang yaitu: mendistribusikan dan/atau mentransmisikan dan/atau membuat dapat diaksesnya informasi elektronik dan/atau dokumen elektronik yang memiliki muatan yang melanggar kesusilaan. Dalam hal ini jelas ditegaskan hanya tiga perbuatan atau kelakuan tersebut yang dapat dikenakan pidana oleh pasal ini, selain itu tidak ternasuk terkena pidana oleh pasal ini. Dalam perspektif subjek yang terkena keberlakuan dari undang-undang ITE adalah semua orang pada umumnya baik itu yang telah dewasa maupun anak-anak. ${ }^{38}$

Sanksi pidana pasal 27 ayat (1) terdapat pada pasal 45 ayat (1) yaitu hukuman pidana penjara paling lama 6 (enam) tahun dan/atau denda paling banyak Rp. 1.000.000.000,00 (satu miliar rupiah).

Terdapat beberapa hal yang harus diperhatikan dalam pasal 27 ayat (1), diantaranya, yang pertama,dalam hal penerapan pelaku (subjek hukum). Pelaku yang dapat dijerat oleh ketentuan ini adalah pihak yang mendistribusikannya, mentransmisikan dan/atau membuat dapat diaksesnya Informasi elektronik dan/atau dokumen elektronik yang mempunyai muatan melanggar kesusilaan, sedangkan pihak yang memproduksi dan yang menerima distribusi dan transmisi tersebut tidak dapat dijerat dengan pasal ini. Selain itu juga pihak yang mengakses informasi elektronik dan/atau dokumen elektronik yang memiliki

37 Ibid., h. 109.

38Ibid., h. 111.

Al-Qānūn, Vol. 20, No. 2, Desember 2017 
muatan yang melanggar kesusilaan juga tidak dapat dipidana oleh pasal ini. Terdapat tiga pihak yang bekerja dalam hal mewabahnya pornografi di internet, yaitu : yang memproduksi (produsen atau pembuat), yang menyebarkan (distributor), yang menerima penyebaran dan/atau pihak yang mengakses. ${ }^{39}$

Sedangkan untuk produsen dan pemilik perangkat lunak dan perangkat keras dalam hal program muatan pornografi tidak dijerat dengan pasal ini tetapi dikenakan dengan pasal 34 ayat (1) dan dikenakan sanksi pidana sebagaimana ditentukan dalam Pasal 50 UU Nomor 11 Tahun 2008 Tentang Informasi dan Transaksi Elektronik. Dimana ancaman pidananya lebih berat daripada pasal 45 yang diperuntukan untuk distributor.

Yang kedua, dalam hal muatan informasi elektronik dan/atau dokumen elektronik. Pasal ini mengatur pelanggaran dalam hal penyebaran informasi elektronik dan/atau dokumen elektronik yang memiliki muatan melanggar kesusilaan. Pelanggaran terhadapnya, termasuk pelanggaran terhadap kesopanan. ${ }^{40}$

\section{Pornografi ditinjau dari Hukum Pidana Islam}

\section{Batasan Pornografi dalam Islam}

Dalam perspektif Islam, pembicaraan tentang pornografi tidak dapat dipisahkan dengan pembicaraan tentang aurat, tabarruj (berpenampilan seronok), dan pakaian. Unsur yang terpenting dalam konsep pornografi adalah melanggar kesusilaan dan membangkitkan nafsu seks. Sedangkan dalam terminologi Islam persoalan tersebut erat kaitannya dengan persoalan aurat dan pakaian. Perintah untuk memelihara kemaluan dan larangan memperlihatkan bagian tubuh yang tidak biasa tampak pada orang lain adalah mencegah timbulnya rangsangan pada diri seseorang terhadap orang yang tidak halal baginya, karena

\footnotetext{
${ }^{39}$ Ibid., h. 165.
}

40 Ibid., h. 170.

Al-Qānūn, Vol. 20, No. 2, Desember 2017 
yang demikian tersebut merupakan pintu atau peluang terjadinya perzinaan. ${ }^{41}$

Larangan dan perintah ini merupakan landasan untuk melarang pornografi dan cyberporn (pornografi di dunia maya), dimana seseorang bisa mengumbar tubuhnya untuk dilihat orang lain dan mengumbar pandangan untuk melihat bagian-bagian tubuh orang lain yang bukan pasangannya yang sah. Perbuatan tersebut merupakan perbuatan awal terjadinya perzinaan, perbuatan cabul, pelecehan seksual bahkan perkosaan. Disamping itu dengan mengumbar pandangan pada gambar atau foto atau video atau film porno di dunia maya juga dapat menimbulkan seseorang untuk melakukan zina di dunia maya atau yang dikenal dengan cyber adultery. ${ }^{42}$

Sedangkan dalam QS. al-Nūr (24): 31 dijelaskan, yanga rtinya: "Katakanlah kepada wanita yang beriman: "Hendaklah mereka menahan pandangannya, dan kemaluannya, dan janganlah mereka Menampakkan perhiasannya, kecuali yang (biasa) nampak dari padanya. dan hendaklah mereka menutupkan kain kudung kedadanya, dan janganlah Menampakkan perhiasannya kecuali kepada suami mereka, atau ayah mereka, atau ayah suami mereka, atau putera-putera mereka, atau putera-putera suami mereka, atau saudara-saudara laki-laki mereka, atau putera-putera saudara lelaki mereka, atau putera-putera saudara perempuan mereka, atau wanita-wanita Islam, atau budakbudak yang mereka miliki, atau pelayan-pelayan laki-laki yang tidak mempunyai keinginan (terhadap wanita) atau anak-anak yang belum mengerti tentang aurat wanita. dan janganlah mereka memukulkan kakinyua agar diketahui perhiasan yang mereka sembunyikan. dan bertaubatlah kamu

${ }^{41}$ Neng Djubaedah, Perzinaan, (Jakarta: Kencana, 2010), h. 157.

42 Ismayawati Any, "Positivisasi Hukum Islam di Indonesia dalam menanggulangi Cyberporn”, al-'Adalah, No. 01 (Juni, 2014), h. 145. 
sekalian kepada Allah, Hai orang-orang yang beriman supaya kamu beruntung."43

Berdasarkan ayat diatas juga menjelaskan tentang perintah Allah agar laki-laki maupun wanita memelihara pandangan adalah karena pandangan merupakan sebab menuju zina. Perintah tersebut apabila dikaitkan dengan pornografi sangat relevan untuk dijadikan dasar pelarangan. Dimana pornografi adalah perbuatan seseorang yang mengumbar pandangannya tidak hanya pada wajahnya saja bahkan sampai melihat keseluruh bagian tubuhnya, dengan melihat gambar atau foto atau video atau film wanita-wanita yang terbuka auratnya, sedangkan wanita-wanita tersebut bukan yang halal baginya. ${ }^{44}$

Maka batasan pornografi dalam Islam adalah sesuai dengan batasan aurat yang telah dijelaskan dalam Islam yaitu Ulama sepakat bahwasanya aurat laki-laki ialah anggota tubuh yang terdapat diantara pusar dan lutut, dan oleh karena itu diboleh kan melihat seluruh badannya kecuali yang tersebut diatas. Bila demikian itu tidak menimbulkan fitnah dan batasan aurat wanita itu adalah seluruh tubuhnya kecuali wajah dan telapak tangan. Serta batasan pandangan yang harus dilakukan seseorang agar tidak menimbulkan nafsu seks. ${ }^{45}$

\section{Pandangan MUI tentang Pornografi}

Terkait dengan masalah pornografi/aksi, sejak tahun 2001 Majelis Ulama Indonesia (MUI) telah mengeluarkan fatwa No. 287 yang berisi penolakan terhadap pornografi/aksi. Dasar-dasar yang digunakan MUI dalam mengeluarkan fatwa tersebut adalah: ${ }^{46}$

43 Kementerian Agama RI, Al-Qur'an Tajwid dan Terjemahnya di Lengkapi dengan Asbabun Nuzul dan Hadits Sahih, (Bandung : PT Sygma Examedia Arkanleema, 2007), h. 352.

${ }^{44}$ Neng Djubaedah, Pornografi dan Pornoaksi, h. 85.

45 Ibid,., 90.

46 Tim Penyusun, Fatwa MUI tentang Pornografi dan Pornoaksi, (Surabay: MUI Jatim, 2012), h. 2. 
a. QS. al-Nūr (24): 30, yang mengatur tentang tata pergaulan dan berbusana kaum laki-laki.

b. QS. al-Nūr (24): 31, yang mengatur tentang tata pergaulan dan berbusana kaum perempuan.

c. QS. al-Aḥzāb (33): 59, yang memerintahkan kepada Nabi Muhammad SAW agar kaum perempuan menulurkan jilbabnya keseluruh tubuhnya (tata busana) agar mudah dikenal dan tidak diganggu.

d. QS. al-Māidah (5): 2, tentang perintah agar setiap orang saling tolong-menolong dalam kebajikan dan takwa.

e. HR. Ahmmad Hadis No. 20787 dan HR. Mālik Hadis No. 1420 , tentang larangan pakaian tembus pandang, erotis, sensual, dan sejenisnya serta H.R Abu Daud tentang aurat perempuan. ${ }^{4}$

f. HR. Al-Bukhāry Hadis No. 2784, tentang larangan berduaan antara laki-laki dengan perempuan bukan mahram serta HR. Muslim tentang penghuni neraka diantaranya kaum perempuan berlenggak-lenggok menggoda atau memikat.

g. Ka'idah ushul al-fiqh yang menyatakan bahwa semua hal yang dapat menyebabkan terjadinya perbuatan haram adalah haram.

h. Kaidah-kaidah fiqh, sebagai berikut:

1)

"Menghindarkan mafsadat didahulukan atas mendatangkan maslahat".

2) الضَّرَرُ يُزَالْ

"Bahaya harus dihilangkan".

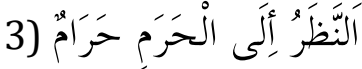

"Melihat pada (sesuatu) yang haram adalah haram".

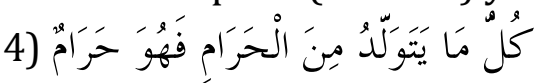

47 Ibid., h. 5.

Al-Qānūn, Vol. 20, No. 2, Desember 2017 
"Segala sesuatu yang lahir (timbul) dari sesuatu yang haram adalah haram". ${ }^{48}$

Berdasarkan pertimbangan-pertimbangan tersebut maka, Majelis Ulama Indonesia (MUI) mengeluarkan fatwa No. 287 tahun 2001 tentang Pornografi/aksi dengan keputusan hukum sebagai berikut: 49

a. Menggambarkan, secara langsung atau tidak langsung, tingkah laku secara erotis, baik dengan lukisan, gambar, tulisan, suara, reklame, iklan, maupun ucapan, baik melalui media cetak maupun elektronik yang dapat membangkitkan nafsu birahi adalah haram.

b. Membiarkan aurat terbuka dan atau berpakaian ketat atau tembus pandang dengan maksud untuk diambil gambarnya, baik untuk dicetak maupun divisualisasikan adalah haram.

c. Melakukan pengambilan gambar sebagaimana dimaksud angka 2 diatas adalah haram.

d. Melakukan hubungan seksual atau adegan seksual dihadapan orang, melakukan pengambilan gambar hubungan seksual atau adegan seksual, baik terhadap diri sendiri maupun orang lain, dan melihat hubungan seksual atau adegan seksual adalah haram.

e. Memperbanyak, mengedarkan, menjual, membeli dan melihat atau memperlihatkan gambar orang, baik cetak atau visual, yang terbuka auratnya atau berpakaian ketat atau tembus pandang yang dapat membangkitkan nafsu birahi, atau gambar hubungan seksual atau adegan seksual adalah haram.

f. Berbuat intim atau berdua-duaan (khalwat) antara lakilaki dengan perempuan yang bukan mahramnya, dan perbuatan sejenis lainnya yang mendekati dan atau mendorong melakukan hubungan seksual di luar penikahan adalah haram. 
g. Memperlihatkan aurat, yakni bagian tubuh antara pusar dan lutut bagi laki-laki dan bagian tubuh selain muka, telapak tangan,dan telapak kaki bagi perempuan, adalah haram, kecuali dalam hal-hal yang dibenarkan secara syar'i.

h. Memakai pakaian tembus pandang atau ketat yang dapat memperlihatkan lekuk tubuh adalah haram.

i. Melakukan suatu perbuatan dan atau suatu ucapan dapat mendorong terjadinya hubungan seksual diluar penikahan atau perbuatan sebagaimana dimaksud angka 6 adalah haram.

j. Membantu dengan segala bentuknya dan atau membiarkan tanpa pengingkaran perbuatan-perbuatan yang diharamkan diatas adalah haram.

k. Memperoleh uang, manfaat, dan atau fasilitas perbuatan-perbuatan yang diharamkan di atas adalah haram.

\section{Sanksi Pornografi dalam Islam}

Pornografi dalam hukum Islam sudah jelaskeharamannya, karena merupakan perbuatan yang menghantarkan kepada perkara yang diharamkan oleh Allah SWT yaitu perzinaan, maka Islam sangat melarang bahkan untuk sekedar mendekatinya. ${ }^{50}$ Berdasarkan QS al-Isrā' (17): 32, yang artinya: "Dan janganlah kamu mendekati zina; Sesungguhnya zina itu adalah suatu perbuatan yang keji. dan suatu jalan yang buruk." 51

Dalam ayat tersebut dikatakan "jangan mendekati zina", makna yang terkandung dari ayat tersebut adalah larangan melakukan perbuatan yang mengarah atau menyebabkan orang melakukan zina, makna lebih lanjut adalah perbuatan zina lebih dilarang, karena mendekati saja sudah dilarang. Disamping itu, dalam syariat Islam terdapat suatu kaidah yang berbunyi:

50 Neng Djubaedah, Pornografi, h. 97.

${ }^{51}$ Kementerian Agama RI, Al-Qur'an Tajwid dan Terjemahnya, h. 282. 


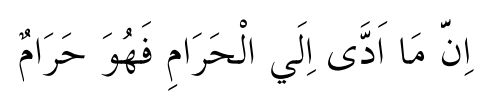

"Setiap perbuatan yang mendatangkan kepada haram maka hukumnya haram".

Dengan demikian berdasarkan kaidah ini setiap perbuatan yang pada akhirnya akan mendatangkan dan menjerumus kepada perbuatan zina merupakan perbuatan yang dilarang dan diancam oleh hukuman $\mathrm{Ta}^{\prime} z \bar{i}{ }^{52}{ }^{52} \mathrm{Hal}$ ini dijelaskan pula dalam dalam sebuah Hadist. Dari Abu Hurairah, Nabi saw bersabda: "Pasti dicatat bagi anak adam bagiannya daripada zina. Ia pasti mengetahuinya : dua mata berzina dengan memandang, dua telinga berzina dengan mendengar, lisan berzina dengan berbicara, tangan berzina dengan memegang, kaki berzina dengan melangkah, hati berzina dengan menginginkan dan berkhayal dan itu akan dibenarkan dan didustakan oleh kemaluan." (HR. Bukhari dan Muslim). ${ }^{53}$

Dari dalil diatas, maka dapatlah ditarik kesimpulan didalam Islam mengenai dua kategori perbuatan zina.

a. Zina yang menyebabkan jatuhnya hukuman (hadd), yaitu zina kemaluan, homoseks atau lesbian atau dengan binatang (liwat) dan dengan mayat.

b. Zina yang tidak menyebabkan jatuhnya hukuman, tapi tetap menyebabkan pelakunya berdosa yaitu zina mata, telinga, berbicara, kaki, dan pikiran dengan mengkhayalnya. ${ }^{54}$

Pornografi dalam kaitannya dengan Hukum Islam ini, masuk dalam kategori zina yang kedua, yaitu tidak sampai terkena hukuman langsung (hadd), namun tetap membuat pelakunya berdosa. Dalam hal cyberporn daya rangsangnya terhadap hasrat seksual seseorang, terbesar memang

52 Ahmad Mawardi Muslich, Hukum Pidana Islam, (Jakarta: Sinar Grafika, 2005), h. 9.

${ }^{53}$ A Djazuli, Fiqih Jinayah, (Jakarta: Raja Grafindo Persada, 2000), h. 61.

54 Ibid., h. 62.

Al-Qānūn, Vol. 20, No. 2, Desember 2017 
melalui pandangan mata, baru kemudian melalui pendengaran. ${ }^{55}$

Di samping itu, Islam pun mengharamkan menceritakan hubungan intim suami-istri, meskipun hanya diceritakan kepada istrinya yang lain. Apalagi dipertontonkan kepada khalayak. Rasulullah bersabda:

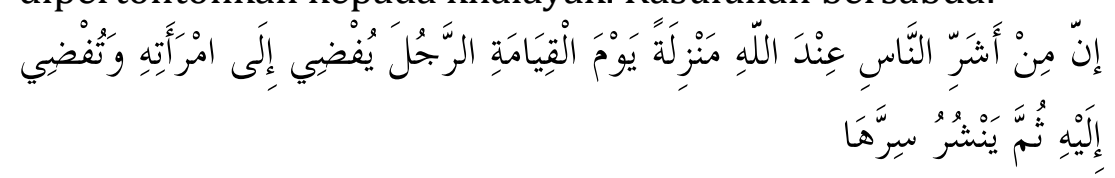

“Sesungguhnya manusia yang paling jelek kedudukannya di sisi Allah pada Hari Kiamat ialah seseorang yang menyetubuhi istrinya dan istri bersetubuh dengan suaminya, kemudian suami menyebarkan rahasia istrinya". (HR Muslim dari Abi Said al-Khudri). ${ }^{56}$

Dengan keras Nabi saw. menggambarkan mereka seperti setan:

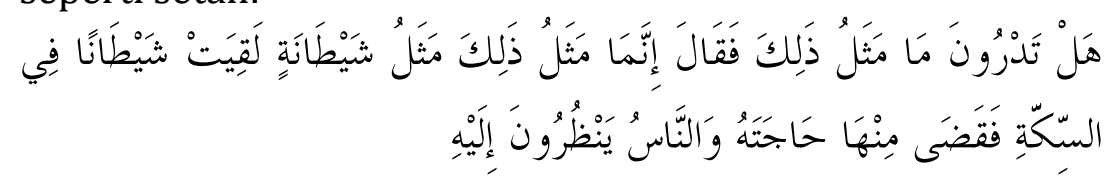

"Tahukah apa permisalan seperti itu?" Kemudian beliau berkata, "Sesungguhnya permisalan hal tersebut adalah seperti setan wanita yang bertemu dengan setan laki-laki di sebuah gang, kemudian setan laki-laki tersebut menunaikan hajatnya (bersetubuh) dengan setan perempuan, sementara orang-orang melihat kepadanya." (HR Abu Dawud) ${ }^{57}$

Barang siapa mencetak atau menjual atau menyimpan dengan maksud untuk dijual atau disebarkan, atau menawarkan benda-benda perhiasan yang dicetak atau ditulis dengan tangan, atau foto-foto serta gambar-gambar

55 Ismayawati Any , Positivisasi Hukum Islam, h. 160.

56 Abdur Rahman, Tindak Pidana dalam Syariat Islam, (Jakarta: Rineka Cipta, 1992), h. 31.

57 Ibid., h. 36. 
porno atau benda lainnya yang dapat menyebabkan kerusakan akhlak maka pelakunya akan dihukumi $t a^{\prime} z i{ }^{5}{ }^{58}$

Secara bahasa ta'zir bermakna al-man'u (pencegahan). Menurut istilah ta'zir bermakna, at-ta'dib (pendidikan) dan at-tankil (pengekangan). ${ }^{59}$ Adapun definisi ta'zir secara shar'iy yang digali dari nash-nash yang menerangkan tentang sanksi-sanksi yang bersikap edukatif, adalah sanksi atas jarimah-jarimah yang hukumannya belum ditetapkan oleh shara', jarimah ta'zir terdiri dari perbuatanperbuatan maksiat yang tidak dikenakan hukuman hadd dan tidak pula kaffarah.60 Inti dari jarimah ta'zír adalah perbuatan maksiat, adapun yang dimaksud maksiat adalah meninggalkan perbuatan yang diwajibkan dan melakukan perbuatan yang diharamkan (dilarang) ${ }^{61}$

Ta'zir telah disyari'atkan bagi setiap pelanggaran shar'iy yang tidak menetapkan ukuran sanksinya, maka sanksinya diserahkan kepada penguasa untuk menetapkan jenis sanksinya. Sanksi semacam inilah yang dinamakan oleh ta'zir. Sanksi ta'zir ditetapkan sesuai dengan tingkat kejahatannya. Kejahatan yang besar pasti dikenai sanksi yang berat, sehingga tercapai tujuan sanksi yakni pencegahan. Begitu pula dengan kejahatan kecil akan dikenai sanksi yang dapat mencegah orang lain untuk melakukan kejahatan serupa. ${ }^{62}$ Sebagian fuqaha' telah menetapkan bahwa ta'zir tidak boleh melebihi hüdüd. Mereka berpendapat, bahwa ta'zir tidak boleh melebihi kadar sanksi hadd yang dikenakan pada jenis kemaksiatan. Berdasarkan hadist yang diriwayatkan oleh Abi Bardahdari Nabi saw, bahwa beliau bersabda :

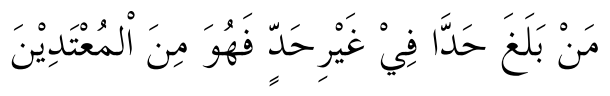

58 Abdurrahmman al-Maliki, Sistem Sanksi dalam Islam, (Bogor: Pustaka Thariqul Izzah, 2002), h. 288.

${ }^{59}$ Ibid., h. 239.

60 Ibid., h. 240.

61 Ibid., h. 241.

62Ibid., h. 243.

Al-Qānūn, Vol. 20, No. 2, Desember 2017 
"Barangsiapa melebihi had pada selain had (hudud), maka ia termasuk kaum yang melampaui batas"63

Penetapan kadar sanksi ta'zir asalnya merupakan hak bagi khalifah. meskipun demikian sanksi ta'zir boleh ditetapkan berdasarkan ijtihad seorang qädi. Boleh juga khalifah melarang qädi untuk menetapkan ukuran sanksi ta'zir, dan khalifah sendiri yang menetapkan ukuran sanksi ta'zirnya kepada qādi, sebab qādi adalah wakil khalifah. Sedangkan peradilan tergantung dengan zaman, tempat dan kasus yang terjadi. Khalifah boleh memberi hak khusus kepada qädi untuk memutuskan persoalan-persoalan peradilan tertentu. Khalifah juga yang berhak melarang qädi untuk menetapkan sanksi ta'zir secara mutlak. Bahkan khalifah juga berhak melarang qädi untuk menetapkan ukuran sanksi ta'zïr secara mutlak. ${ }^{64}$

Perbuatan-perbuatan yang dihukumi ta'zīr sulit diklasifikasikan jenis-jenisnya karena $t a^{\prime} z \bar{i} r$ berbeda dengan hudud, artinya pada umunya ta'zír terjadi pada kasus-kasus yang belum ditetapkan ukuran sanksinya oleh shara', oleh karena itu penetapan sanksi ta'zír lebih didasarkan pada status sanksi atau perbuatan yang telah diklasifikasikan jenis. Atas dasar ini perbuatan yang dapat dihukumi ta'zir telah ditetapkan menjadi tujuh jenis diantaranya adalah Pelanggaran terhadap kehormatan (perbuatan-perbuatan cabul, perbuatan melanggar kesopanan, perbuatan yang berhubungan dengan suami istri), Pelanggaran terhadap kemuliaan atau harga diri, Perbuatan yang merusak akal, Pelanggaran terhadap harta (benda yang bergerak, penipuan, pengkhianatan terhadap amanah harta, penipuan dalam muamalat, pailit, ghashab), Gangguan keamanan negara yang meliputi penulis dan propagandanya, organisasi atau partai, spionase, agen, makar-makar, Subversi serta Perbuatan yang berhubungan dengan agama. ${ }^{65}$

63Ibid., h. 244.

64 Ibid., h. 245.

65 Ibid., h. 285

Al-Qānūn, Vol. 20, No. 2, Desember 2017 
Bentuk ta'zir yang digunakan syari' sebagai hukuman adalah sanksi hukuman mati, jilid, penjara, pengasingan, alhijr, salib, gharamah, melenyapkan harta, mengubah bentuk barang, tahdìd al-șadiq, wa'dh,hirmān, taubikh, tashhïr. Selain sanksi-sanksi tersebut penguasa tidak boleh menjatuhkannya sebagai sanksi, meskipun tidak ada nash dan shar'iy yang melarangnya. Itu disebabkan karena sanksi adalah perbuatan sehingga harus ada dalil yang menunjukkan kebolehannya. ${ }^{66}$

Jika terbukti seseorang melakukan kejahatan pornografi, maka bentuk dan kadar sanksinya diserahkan kepada had qadhi, bisa dalam bentuk tasyhir (diekspos), di penjara, dicambuk dan bentuk sanksi lain yang dibenarkan oleh syariah. Jika materi pornografi disebarkan secara luas sehingga bisa menimbulkan bahaya bagi masyarakat, tentu bentuk dan kadar sanksinya bisa diperberat sesuai dengan kadar bahaya yang ditimbulkan bagi masyarakat itu. Adapun dari sisi dosa, ia seperti melakukan investasi dosa, yang dosanya tetap mengalir kepadanya walaupun dia sudah meninggal. Rasulullah bersabda: "Barang siapa memberikan suri tauladan yang buruk dalam Islam, lalu suri tauladan tersebut diikuti oleh orang-orang sesudahnya, maka akan dicatat baginya dosa sebanyak yang diperoleh orang-orang yang mengikutinya tanpa mengurangi dosa yang mereka peroleh sedikitpun." (HR. Muslim)

Dijelaskan pula oleh Al Hafiz al Mundziry (wafat 656 H) dalam kitabnya At-Targhib wa At-Tarhib (1/62) menyatakan:

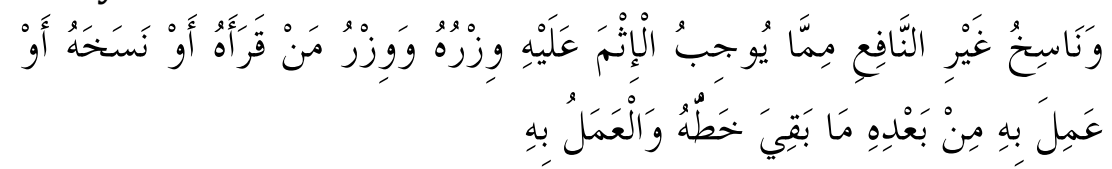

"Orang yang menulis hal yang tidak bermanfaat adalah diantara sesuatu yang mewajibkan dosa, baginya dosanya

66 Ibid., h. 275.

Al-Qānūn, Vol. 20, No. 2, Desember 2017 
dan dosa orang yang membacanya atau menyalinnya atau beramal dengannya sesudahnya selama tulisan tersebut dan beramal dengannya masih tetap ada". ${ }^{67}$

Dengan demikian, sanksi pornografi dalam hukum pidana Islam adalah ta'zir yang penetapan kadar sanksi merupakan hak bagi Khalifah sesuai dengan tingkat kejahatan yang dilakukan.

\section{E. Penutup}

Dari berbagai pemaparan di atas maka dapat disimpulkan sebagai berikut:

1. Pornografi merupakan penggambaran tubuh manusia atau perilaku seksualitas manusia secara terbuka dengan tujuan membangkitkan birahi. Jika penyebarannya melalui media internet maka disebut cyberporn. Dampak mengkonsumsi pornografi adalah efek negatif bagi perkembangan psikologis dan biologis.

2. Pronografi dalam hokum pidana Indonesia didefinisikan sebagai gambar, sketsa, ilustrasi, foto, tulisan, suara, bunyi, gambar bergerak, animasi, kartun, percakapan, gerak tubuh, atau bentuk pesan lainnya melalui berbagai bentuk media komunikasi dan/atau pertunjukan di muka umum, yang memuat kecabulan atau eksploitasi seksual yang melanggar norma kesusilaan dalam masyarakat. Pengaturannya terdapat dalam KUHP (Pasal 282), dalam Undang-undang Nomor 44 Tahun 2008 tentang Pornografi, dan dalam Undang-undang Nomor 11 Tahun 2008 Tentang Informasi dan Transaksi Elektronik.

3. Pornografi dalam Hukum Islam termasuk zina yang tidak sampai terkena hukuman (ḥadd), namun tetap membuat pelakunya berdosa. Sanksi bagi pelaku pornografi adalah ta'zir, yang penetapan kadar sanksi

67 Imam Ghazali, "Konsep Islam dalam Memberantas Pornografi", dalam https://mtaufiknt.wordpress.com/2012/03/16/konsep-islamdalam-pemberantasan-pornografi/, diakses 05/04/2017. 
merupakan hak bagi pemimpin negara sesuai dengan tingkat kejahatan yang dilakukan.

\section{Daftar Pustaka}

A. Djazuli. Fiqih Jinayah. Jakarta, Raja Grafindo Persada, 2000.

Abdur Rahman. Tindak Pidana dalam Syariat Islam. Jakarta, Rineka Cipta, 1992.

Abdurrahmman al-Maliki. Sistem Sanksi dalam Islam. Bogor, Pustaka Thariqul Izzah, 2002.

Adi Basuki. "Definisi Internet Pornography", dalam http://encyclopedia.thefreedictionary.com, diakses 05/04/2017.

Adi Budiman. "Pornografi dan Hukum yang Mengaturnya", dalam http://www.pornografi-dan-hukummengaturnya-0=67, diakses 23/04/2017.

Adi Maulana. Blokir Pornografi. Bandung, Nuansa Cendikia, 2012.

Admin.

"Pornografi",

dalam

https://id.wikipedia.org/wiki/Pornografi, diakses 20/01/2017.

Admin. "Pornografi", dalam https://kbbi.web.id/pornografi, diakses 20/01/2017.

Ahmad Mawardi Muslich. Hukum Pidana Islam. Jakarta, Sinar Grafika, 2005.

Andi Hamzah. Delik-delik Tertentu di dalam KUHP. Jakarta, Sinar Grafika, 2014.

Arief. Pornografi Pornoaksi dan Cybersex Cyberporn. Semarang, Pustaka Magister, 2011.

Azimah Soebagijo. Pornografi Dilarang Tapi Dicari. Jakarta, Gema Insani, 2008.

Budi Suhariyanto. Tindak Pidana Teknologi Informasi (Cyber Crime). Jakarta, Rajagrafino Persada, 2013. 
David Le. " All About Bigo Live", dalam http://Www.Bigo.Sg/About.Html, diakses 17/01/2017.

Dimas Maulana. "Bigo live, Kenapa Bisa Tenar?", dalam https://www.kaskus.co.id/thread/578f74fb 507410f0718b456a/aplikasi-bigo-live-kenapa-bisatenar/, diakses 20/01/2017.

Eni Maryani. Media dan Perubahan Sosial. Jakarta, Rosda. 2011.

Hidayat Lubis. Tinjauan Hukum Pidana Islam Terhadap Cyberporn Pada UU RI Nomor 11 Tahun 2008 Tentang Informasi Dan Transaksi Elektronik. Skripsi--UIN Sunan Kalijaga, 2009.

Imam Ghazali.

"Konsep Islam dalam Memberantas Pornografi", dalam

https://mtaufiknt.wordpress.com/2012/03/16/konsepislam-dalam-pemberantasan-pornografi/, diakses 05/04/2017.

Indra Perwira. "Sejarah Pornografi", dalam Bima Sakti, 03, (15 Mei 2015).

Ismayawati Any. "Positivisasi Hukum Islam di Indonesia dalam menanggulangi Cyberporn", al-'Adalah, No. 01 (Juni, 2014).

Kementerian Agama RI. Al-Qur'an Tajwid dan Terjemahnya di Lengkapi dengan Asbabun Nuzul dan Hadits Sahih. Bandung, Sygma Examedia Arkanleema, 2007.

Muhammad Ihrom. "Pornografi di Internet", dalam https://muhammad26ihrom.wordpress.com/cybercrime-dan-cyber-law/pornografi-di-internet, diakses 09/03/2017.

Nana Mandani. "Mengapa Wanita Rela Umbar Aurat di Bigo Live?Ternyata ini Imbalannya", dalam Tribun News, (27 Agustus 2016).

Neng Djubaedah. Pornografi dan Pornoaksi Ditinjau dari Hukum Islam. Jakarta, Kencana, 2003. 
Rahma Maula. "Devinisi Cyberporn", dalam http://www.computeruser.com/resaurces/dictionary/se archer.html?q=1\&obj=C, diakses 05/04/2017.

Soetandyo Wignjosoebroto. Pergeseran dalam Kajian-kajian Sosial dan Hukum. Bandung, Setara Press, 2013.

Tim Penyusun. Fatwa MUI tentang Pornografi dan Pornoaksi. Surabaya, MUI Jatim, 2012. 